\title{
PURPLE ROSELLA (Hibiscus sabdariffa Linn.) PETAL EXTRACT PREVENTS HEPATOCYTE DEGENERATION IN WISTAR RATS EXPOSED TO CIGARETTE SMOKE
}

\author{
Arya Ulilalbab ${ }^{1}$, Bambang Wirjatmadi ${ }^{2}$, Merryana Adriani ${ }^{2}$ \\ ${ }^{1}$ Karya Husada Academy of Nutrition, Kediri, ${ }^{2}$ Master Program of Public Health, Faculty of Public Health, \\ Universitas Airlangga, Surabaya, Indonesia
}

\begin{abstract}
ABSTRAK
Saat ini, jumlah perokok di Indonesia masih tinggi. Asap rokok mengandung radikal bebas. Penelitian ini bertujuan untuk menganalisis pengaruh ekstrak kelopak rosella ungu terhadap pencegahan degenerasi hepatosit tikus Wistar yang dipapar asap rokok. Total sampel 20 tikus jantan dan dibagi menjadi empat kelompok: kontrol negatif, kontrol positif, perlakuan ekstrak kelopak rosella ungu dosis $270 \mathrm{mg} / \mathrm{kg} \mathrm{BB}$, dan ekstrak kelopak rosella ungu dosis $540 \mathrm{mg} / \mathrm{kg} \mathrm{BB}$. Kontrol negatif hanya diberi pakan standar. Kontrol positif diberi pakan standar dan dipapar 2 rokok per hari. Kelompok perlakuan diberi pakan standar dan ekstrak rosella di pagi hari dan setelah itu dipapar 2 batang rokok sampai rokok tersebut habis dan dilakukan setiap hari. Penelitian ini dilakukan selama 28 hari. Di akhir penelitian, dibuat sediaan histopatologi hepar dengan pewarnaan hematoxilin eosin untuk dilihat degenerasi hepatosit. Pemberian ekstrak kelopak rosella ungu dosis $540 \mathrm{mg} / \mathrm{kg} \mathrm{BW}$ dan dosis $270 \mathrm{mg} / \mathrm{kg}$ BB secara bermakna (p < $0,05)$ dapat mencegah degenerasi hepatosit. Ekstrak kelopak rosella ungu dapat mencegah degenerasi hepatosit pada tikus Wistar yang dipapar asap rokok. (FMI 2018;54:96-101)
\end{abstract}

Kata kunci: Antioksidan; radikal bebas; degenerasi hepatosit; rosella ungu

\begin{abstract}
Currently, the number of smokers in Indonesia is still high. Cigarette smoke contains free radicals. This study aimed to analyze the effects of purple rosella petal extract on the prevention of hepatocyte degeneration in Wistar rats exposed to cigarette smoke. Twenty male rats were divided into four groups: negative control, positive control, treatment group receiving $270 \mathrm{mg} / \mathrm{kg} \mathrm{BW} \mathrm{purple} \mathrm{rosella}$ petal extract, and treatment group receiving $540 \mathrm{mg} / \mathrm{kg} B W$ purple rosella calyx extract. Negative control was only given with standard feed. Positive control was given with standard feed and exposed to 2 cigarettes a day. Treatment groups were fed with standard feed and administered with rosella extract in the morning then exposed to 2 cigarettes every day. This study was conducted for 28 days. At the end of the study, hepatocyte degeneration was observed in liver histopathology stained with hematoxilin eosin. The administration of purple rosella petal extracts in the doses of $540 \mathrm{mg} / \mathrm{kgBW}$ and $270 \mathrm{mg} / \mathrm{kgBW}$ significantly (p<0.05) prevented hepatocyte degeneration. Purple rosella petal extract is able to prevent hepatocyte degeneration in Wistar rats exposed to cigarette smoke. (FMI 2018;54:96-101)
\end{abstract}

Keywords: Antioxidant; free radical; hepatocyte degeneration; purple rosella

Correspondence: Arya Ulilalbab, Karya Husada Academy of Nutrition, Jalan Soekarno Hatta 7, Pare, Kediri. Phone: 085755211490. Email: arya17051990@gmail.com

\section{INTRODUCTION}

Smoking is familiar to Indonesians. Smoking behavior among the population of $>15$ years of age in Indonesia in 2007 was found in as much as $34.2 \%$. There was an increase of the prevalence of smoking behavior in the population as shown from the results of RISKESDAS 2013 which was $36.3 \%$ (Kemenkes 2015). Smoking habits in society is difficult to stop. Nicotine in cigarettes can cause addiction and disorders of the heart and lungs (Voges 2000). However, eliminating smoking habit is not easy. Cigarette smoke contains free radicals that harm the body, thus an innovation is necessary to develop product that can minimize negative impacts caused by cigarettes.

Chemical components contained in cigarette smoke are in the form of gas and particles (Tirtosastro \& Murdiyati 2010), some of which are radical. Although most free radicals are short-lived, the radicals of nitric oxide and quinones can reach the lungs (Subandi 1999). From the lungs, free radicals are carried by the bloodstream to the heart and are circulated throughout the body, including to the liver (Guyton \& Hall 1997). This leads to complex biochemical changes that can ultimately lead to liver cell damage (Soini \& Lehto 1998). 
Exposure to cigarette smoke can cause hepatic cell necrosis (Muliartha et al 2009). The liver is one of the most vulnerable organs since it is a filter of toxic substances that enter the body. In addition, the liver has a double circulatory system (Vollmar \& Menger 2009), so the accumulation of toxic materials in the liver is higher. Free radicals produced by toxic substances can cause hepatocyte damage (Jawi et al 2006). In addition to causing hepatic damage, cigarette smoke may damage the alveolar lung (Marwan et al 2006), leading to a reduction in the number of spermatogonium cells in rat testis (Wistar strain Rattus norvegicus) (Kurnia et al 2011), leading to increased levels of malondialdehyde (MDA) (Nasution et al 2016, Kurnia et al 2011, Ambrose \& Barua 2004, Jain et al 2009). MDA is a biomarker that indicates oxidative stress has occurred.

Ironically, many people are unaware of the negative effects of smoking, even though the dangers are listed in the cigarette packs saying that smoking can cause cancer, heart attacks, impotence, pregnancy and fetal disorders. The impact is related to the presence of free radical content in cigarette smoke, such as $\mathrm{NO}, \mathrm{CO}$, $\mathrm{NOx}, \mathrm{H} 2-\mathrm{O} 2$, aldehydes, trace elements and nitroso compounds (Valvanidis \& Haralambous 2001). Free radicals can cause oxidative stress which is the results of degenerative diseases. The source of free radicals can be from motor vehicle fumes, waste cooking oil, and cigarette smoke (Park et al 1998).

Normally, free radicals are present in the body (endogenous free radicals). The body naturally also has antioxidants as inhibitors that act to inhibit oxidation by reacting with free radicals to form relatively free radicals. However, if the free radicals are excessive, then the natural antioxidants are not able to cope. In such circumstances the body needs antioxidant supply. Antioxidants are all compounds that can reduce the negative effects of oxidants, especially in the inhibition and cessation of oxidative damage to a target molecule (Simanjuntak \& Sudaryati 1998). Source of antioxidants from outside the body can be found, for example, on rosella petals (Esa et al 2010, Bolade \& Ojo 2009, Hirunpanich et al 2005). Rosella extract at doses of 150 $\mathrm{mg}$ and $300 \mathrm{mg}$ can improve the oxidative stress state, improve endothelial function and decrease the risk of atherosclerosis as characterized by increased SOD activity, decreased amount of F2-isoprostan, ADMA and Foam cell in endothelial tissue of rats receiving an atherogenic diet (Yusmiati et al 2012).

One of the alternatives we proposed in this study was the use of rosella petal extract in water solvent. This is because the rosella extract in the water solvent can be applied as functional food addition. Water solvents are suitable for extracting anthocyanins that have the same polarity as water. In addition, water solvents are chosen because they are safer and easier to apply on a household scale. The extract was taken from rosella petals because it had the highest total antioxidant activity as high as $54.1 \%$ compared to rosella seeds, leaves, or rods (Esa et al 2010). Rosella contains many anthocyanins in which 1 gram of rosella contains 56.5 mg delphinidin-3-O-sambubioside and $20.8 \mathrm{mg}$ cyanidin-3-O-sambubioside (Alarco-Alanso et al 2012). Antioxidants derived from anthocyanin extract of rosella potentially overcome oxidative damage in rat liver induced by CCl4 (Ajiboye et al 2011, Adetutu \& Owoade 2013).

The antioxidants contained in purple rosella effervescent have been shown to be effective in preventing hepatic necrosis in Wistar rats (Maulana et al 2014) and counteracting free radicals from waste cooking oil (Ulilalbab et al 2012). Further studies are needed whether antioxidant rosella extract can counteract free radicals from exposure to cigarette smoke. So far, the antioxidant effect on purple rosella petal extract in its ability to counteract free radicals from cigarette smoke is not known. Studies on the benefits of rosella petal extract through testing on experimental animals exposed to cigarette smoke by observing indicators of oxidative stress in the form of hepatocyte degeneration needs to be done. The purpose of this study was to determine the effect of purple rosella petal extract on hepatocyte degeneration of Wistar rats exposed to cigarette smoke.

\section{MATERIALS AND METHODS}

The instruments used in this study were spatula, beaker glass, whatman 42 filter paper, hot plate magnetic stirrer, measuring cylinder, dark bottle, digital scales, vacuum evaporator, mouse cage, drinking bottle for experimental animals, smoking pump, vortex, spectrophotometer, binocular microscope with 400x magnification, OptiLab microscope camera, and hematoxylin eosin. Experimental animals used were Wistar rats (Rattus norvegicus), standard feed, mineral water, clove cigarettes, and purple rosella.

\section{Research design}

This was a laboratory experimental study. The in vivo stage of this study was true experimental laboratory with post test only control group design, while for the treatment, we used complete randomized design (CRD). The samples consisted of 20 male rats of Rattus norvegicus of Wistar strain aged 3-4 months weighing 180-200 g with a healthy condition. Samples were chosen by random sampling to be divided into one group of negative control (normal), one positive control 
group, and two treatment groups. Each group consisted of 5 rats. Negative control (normal) group received standard feed without rosella extract and no exposure to cigarette smoke. Positive control group received standard feed with $1 \mathrm{ml}$ p.o water (orally), then exposured to 2 cigarette smoke. Treatment 1 group received standard feed and $270 \mathrm{mg} / \mathrm{kg}$ BW p.o $1 \mathrm{ml}$ purple rosella extract, then exposured to the smoke of 2 cigarettes. Treatment 2 group received standard feed, $540 \mathrm{mg} / \mathrm{kg} \mathrm{BW}$ p.o $1 \mathrm{ml}$ purple rosella extract, then exposured to the smoke of 2 cigarettes.

The experimental animal feed used was POKPHAND CP 591 with composition of $\leq 13.0 \%$ water, 18.0-20.0\% protein, $\geq 3.0 \%$ fat, $\leq 6,0 \%$ fiber, $\leq 7.0 \%$ ash, $\geq 0.9 \%$ calcium, and $\geq 0.6 \%$ phosphor. The ingredients used in feed formulations included corn, bran, fish meal, soybean meal, coconut meal, meat and bone meal, wheat fraction, peanut cake, flour, canola, vitamin, calcium, phosphate and trace minerals.

The cigarettes used in this study contained $2.1 \mathrm{mg}$ nicotine and $34 \mathrm{mg}$ tar. The dose of smoke exposure was 2 cigarettes/rat/day in the afternoon. Cigarette smoke exposure was done after the administration of rosella extract p.o in the treatment groups. Exposure to cigarette smoke and extract administration were carried out for 28 days. The study was conducted at In Vivo Laboratory, Faculty of Medicine, Wijaya Kusuma University, Pharmacology Laboratory, Brawijaya University, Anatomic Pathology Laboratory, Faculty of Medicine, Universitas Airlangga, and Anatomic Pathology Laboratory, GDC, Dr. Soetomo Hospital, Surabaya.

Each treatment group consisted of five rats. In the early stage, normality analysis with Shapiro-Wilk test and homogeneity test with Levene Statistic were performed. If the data were not homogeneous, non-parametric test was performed using Kruskal Wallis test. Whereas, to observe the differences between each group, MannWhitney test was used. Mean hepatocyte degeneration was defined as the mean of total degenerated hepatic cells in three observations using kraticule in each treatment group. Each observation examined the number of degenerated cells from 100 cells by using microscope in 400x magnification.

\section{RESULTS}

Antioxidant test was done by DPPH method $(\alpha, \alpha$ diphenyl picryl hydrazil) with absorbance of $\lambda=517 \mathrm{~nm}$.
The analysis results of antioxidant activity (DPPH test) of rosella extract are presented in Table 1.

Table 1. Antioxidant activity (DPPH test) of of rosella extract

\begin{tabular}{lc}
\hline \multicolumn{1}{c}{ Samples } & \% Inhibition \\
\hline BHT (butylated hydroxytoluene) & 91.620 \\
$540 \mathrm{mg} / \mathrm{kg} \mathrm{BW}$ & 83.888 \\
$270 \mathrm{mg} / \mathrm{kg} \mathrm{BW}$ & 59.858 \\
\hline
\end{tabular}

The highest antioxidant activity (DPPH test) was BHT (butylated hydroxytoluene) as control (91.620\%), followed by $540 \mathrm{mg} / \mathrm{kg}$ BW purple rosella extract $(83.888 \%)$ and $270 \mathrm{mg} / \mathrm{kg} \mathrm{BW}$ purple rosella extract $(59.858 \%)$.

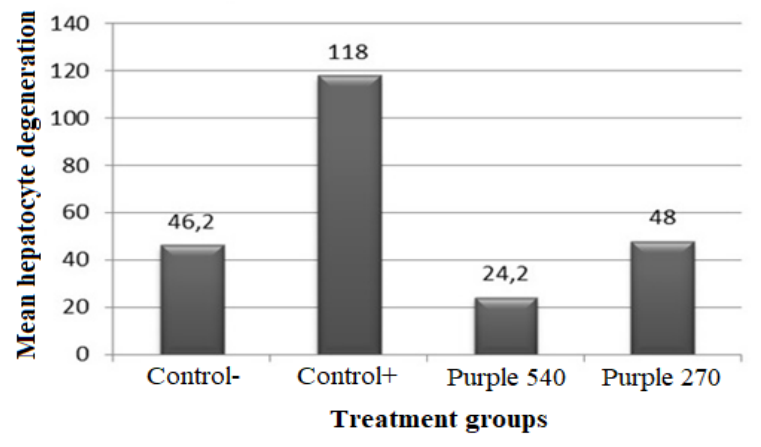

Fig. 1. Mean hepatocyte degeneration

The mean hepatocyte degeneration in the group given with $540 \mathrm{mg} / \mathrm{kg}$ BW purple rosella extract was 24.2. Whereas, mean hepatocyte degeneration in group receiving $270 \mathrm{mg} / \mathrm{kg}$ BW purple rosella extract dose ie 48. Mean hepatocyte degeneration in positive control group was 118 , while mean hepatocyte degeneration in negative control group was 46.2. The highest degree of hepatocyte degeneration was found in positive control group, whereas the lowest was in group receiving purple rosella petal extract dose of $540 \mathrm{mg} / \mathrm{kg} \mathrm{BW}$.

Table 2 shows that the number of hepatocyte degeneration for the group receiving purple rosella extract dose of $270 \mathrm{mg} / \mathrm{kg} \mathrm{BW}$ did not differ significantly from that of the normal group. The hepatocyte count in positive control group was significantly different from all groups, ie purple rosella extract dose of $540 \mathrm{mg} / \mathrm{kg} \mathrm{BW}$, purple rosella extract dose $270 \mathrm{mg} / \mathrm{kg} \mathrm{BW}$, and negative control. Whereas, the negative control group was not significantly different from the group receiving purple rosella extract dose of $270 \mathrm{mg} / \mathrm{kg} \mathrm{BW}$. Negative control group was significantly different from the group receiving purple rosella extract dose of $540 \mathrm{mg} / \mathrm{kg} \mathrm{BW}$ and positive control. 
Table 2. Mean hepatocyte degenerations in different groups

\begin{tabular}{lc}
\hline Groups & Mean hepatocyte degeneration \\
\hline $540 \mathrm{mg} / \mathrm{kg} \mathrm{BW}$ purple rosella extract & 24.2 (a) \pm 3.493 \\
$270 \mathrm{mg} / \mathrm{kg}$ BW purple rosella extract & 48.0 (b) \pm 7.165 \\
Positive control & 118.0 (c) \pm 58.189 \\
Negative control (normal) & 46.2 (b) \pm 6.017 \\
\hline Note: The averages accompanied by the same letter states no significant difference (Mann \\
Whitney test)
\end{tabular}

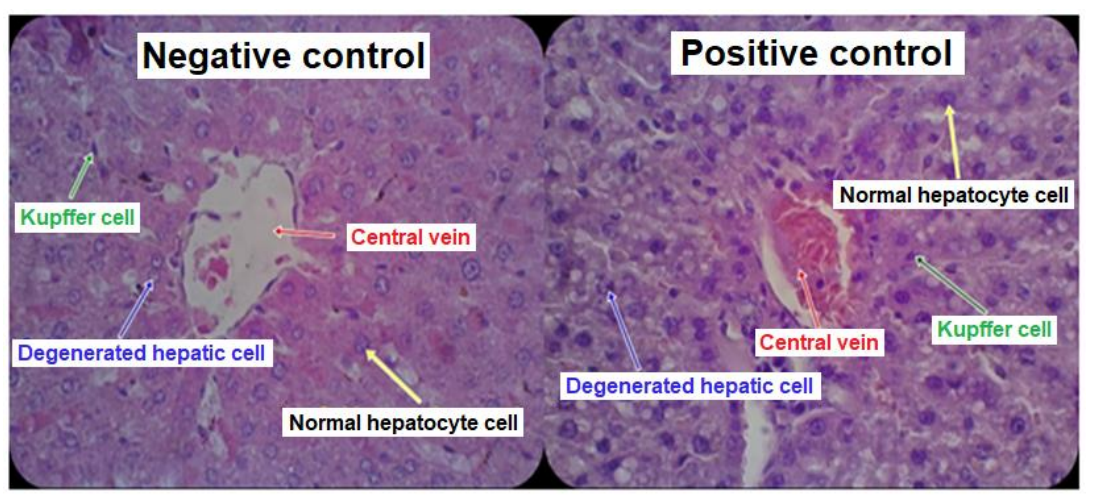

Fig. 2. Hepatic histological section of rats (Rattus norvegicus) with HE staining in negative control group (left) and positive control group (right) in a 400x magnification microscope.

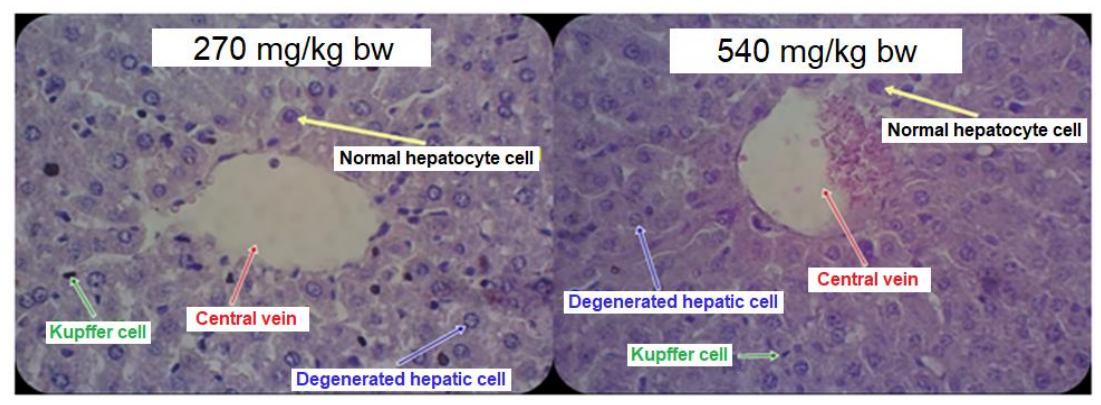

Fig. 3. Hepatic histological section of rats (Rattus norvegicus) with HE treatment in treatment groups receiving purple rosella extract dose of $270 \mathrm{mg} / \mathrm{kg} \mathrm{BW}$ (left) and $540 \mathrm{mg} / \mathrm{kg} \mathrm{BW}$ (right) in 400x magnification microscope. Red arrows indicate central vein, yellow arrow shows normal hepatocyte cells, green arrow indicates kupffer cell, blue arrow indicates cell liver degeneration.

\section{DISCUSSION}

DPPH test results revealed that the highest antioxidant activity of purple rosella petal extract was in BHT (butylated hydroxytoluene) as control, followed by purple rosella petal extract doses of $540 \mathrm{mg} / \mathrm{kg} \mathrm{BW}$ and $270 \mathrm{mg} / \mathrm{kg} \mathrm{BW}$. The higher the dose indicates the higher the value of its antioxidant activity. The main character of the antioxidant compounds is its ability to capture and stabilize free radicals (Prakash 2001). This study found that the group of purple rosella extract dose of $540 \mathrm{mg} / \mathrm{kg} \mathrm{BW}$ had the lowest hepatocyte degeneration. This was because the group received the extract p.o with the highest antioxidant activity (83.888\% inhibi- tion) compared to the other treatment groups. Conversely, positive control group had the highest number of degenerated hepatic cells because the experimental animals in the group were exposed to cigarette smoke alone without the intake of antioxidants. The heavily necrotic liver cells were present in the positive control treatment group (Muliartha et al 2009).

The group receiving purple rosella extract in a dose of $540 \mathrm{mg} / \mathrm{kg}$ BW differed significantly from the other groups. This indicates that giving purple rosella extract dose of $540 \mathrm{mg} / \mathrm{kg} \mathrm{BW}$ provides a remarkable effect on the prevention and reduction of oxidative stress caused by cigarette smoke. In studies on rosella activity as 
antihepatotoxic in streptozotocin-induced rats as indicator of free radical, rosella has been found to have an effect of repairing tissue damage (Adeyemi et al 2014). The group receiving purple rosella extract in a dose of $270 \mathrm{mg} / \mathrm{kg}$ BW did not differ significantly with the negative group, so it can be concluded that the purple rosella extract group of $270 \mathrm{mg} / \mathrm{kg} \mathrm{BW}$ was able to match the normal condition despite being treated with exposure to cigarette smoke. This indicates that the purple rosella dose of $270 \mathrm{mg} / \mathrm{kg} \mathrm{BW}$ is able to prevent hepatocyte degeneration of Wistar rats exposed to cigarette smoke. This is confirmed by some studies suggesting that rosella extract is able to decrease serum aspartate aminotransferase (AST), alanine aminotransferase (ALT) and alkaline phosphatase (ALP) serum activity as biomarkers of hepatic damage (Famurewa et al 2015, Usoh et al 2012).

Groups of rats exposed to tobacco smoke showed higher hepatocyte degeneration rates than the treatment group or negative control group. This is because cigarette smoke contains tar-free radicals or gas components (Muliartha et al 2009). Free radicals from cigarette smoke enter the lungs through the airways, then carried by the bloodstream to the heart and circulated throughout the body, including to the liver (Guyton \& Hall 1997). Oxidants and free radicals present in cigarettes have the potential to trigger lipid peroxidation of cell lipid membranes (Frei et al 1991). ROS (Reactive Oxygen Species) in cigarette smoke triggers the destruction of endogenous antioxidants (enzymatic vitamins and antioxidants), thereby reducing the role of antioxidants in cellular defense (Cross et al 1999).

\section{CONCLUSION}

Purple rosella petal extract is able to prevent hepatocyte degeneration in Wistar rats exposed to cigarette smoke. In this study, treatment group receiving the extract of $540 \mathrm{mg} / \mathrm{kg}$ BW was able to optimally prevent hepatic cell degeneration compared to the group receiving 270 $\mathrm{mg} / \mathrm{kg} \mathrm{BW}$. However, negative control group, which did not receive any extract, also showed hepatocyte degeneration because free radicals are also naturally produced as byproduct of metabolic activity in the body.

\section{REFERENCES}

Adetutu A, Owoade AO (2013). Hepatoprotective and antioxidant effect of hibiscus polyphenol rich extract (Hpe) against carbon tetrachloride $(\mathrm{CCl} 4)$ - Induced damage in rats. British Journal of Medicine and Medical Research 3, 1574-1586
Adeyemi DO, Ukwenya VO, Obuotor EM, et al (2014). Anti-hepatotoxic activities of Hibiscus sabdariffa L. in animal model of streptozotocin diabetes-induced liver damage. Bmc Complementary and Alternative Medicine 14,277

Ajiboye TO, Salawu NA, Yakubu MT, et al (2011). Antioxidant and drug detoxification potentials of Hibiscus sabdariffa anthocyanin extract. Drug and Chemical Toxicology 34, 109-15

Alarco-Alanso J, Zamilpa A, Aguilar FA, et al (2012). Pharmacological characterization of the diuretic effect of Hibiscus sabdariffa Linn (Malvaceae) extract. Journal of Ethnopharmacology 139, 751-6

Ambrose JA, Barua RS (2004). The pathophysiology of cigarette smoking and cardiovascular disease: An update. Journal of the American College of Cardiology 43, 1731-1737

Bolade O, Ojo O (2009). Comercial practice of rosella (Hibiscus sabdariffa L), beverage production. Word Journal of Agricultural Science 5, 126-131

Cross CE, Traber M, Eiserich J, et al (1999). Micronutrient antioxidants and smoking. British Medical Bulletin 55, 691-704

Esa NM, Hern FS, Ismail A, et al (2010). Antioxidant activity in different parts of rosella (Hibiscus sabdariffa $L$.) extracts and potential exploitation of the seeds. Food Chemistry 122, 1055-1060

Famurewa AC, Kanu SC, Uzoegwu PN, et al (2015). Ameliorative effects of Hibiscus sabdariffa extract against carbon tetrachloride-induced lipid peroxidation, oxidative stress and hepatic damage in rats. Journal of Pharmaceutical and Biomedical Sciences 05, 725-732

Frei B, Forte TM, Ames, BN, et al (1991). Gas phase oxidants of cigarette smoke induce lipid peroxidation and changes in lipoprotein properties in human blood plasma. Biochemical Journal 277, 133-138

Guyton, Hall (1997). Buku ajar fisiologi kedokteran. 9th Ed. Jakarta, Penerbit Buku Kedokteran EGC

Hirunpanich V, Utaipat A, Morales NP, et al (2005). Antioxidant effect of aqueous extracts from dried calyx of Hibiscus sabdariffa L. in vitro using rat lowdensity lipoprotein. Biology Pharmacy 28, 481-484

Jain A, Agrawal BK, Varma M, et al (2009). Antioxidant status and smoking habits: Relationship with diet. Singapore Medical Journal. 50, 624-627

Jawi IM, Manuaba IBR, Sutirtayasa IWP, et al (2006). Pemberian glutamin menurunkan kadar bilirubin darah serta mengurangi nekrosis sel-sel hati setelah pemberian aktivitas fisik maksimal dan parasetamol pada mencit. Dexa Medica 4

Kementerian Kesehatan Republik Indonesia (2015). Perilaku merokok masyarakat Indonesia: Berdasarkan RISKESDAS 2007 dan 2013. Jakarta, Pusat Data dan Informasi Kementerian Kesehatan RI, p.1-12 
Kurnia H, Permatasari N, Subandi (2011). Pengaruh ekstrak jintan hitam terhadap MDA dan sel spermatogonium tikus yang dipapar asap rokok kretek subakut. Jurnal Kedokteran Brawijaya 26, 161-165

Marwan, Widjajanto E, Karyono S (2005). Pengaruh pemberian ekstrak biji jinten hitam (Nigella sativa) terhadap kadar GSH, MDA, jumlah serta fungsi sel makrofag alveolar paru tikus wistar yang dipapar asap rokok kronis. Jurnal Kedokteran Brawijaya 21(3): 111-121

Maulana HI, Ulilalbab A, Priyanto AD, et al (2014). Effervescent rosella ungu mencegah penurunan nilai SOD dan mencegah nekrosis hepar tikus wistar yang diberi minyak jelantah. Jurnal Kedokteran Brawijaya 28, 85-90

Muliartha IKG, Sriwahyuni E, Yuliawati (2009). Pemberian kombinasi vitamin $\mathrm{C}$ dan $\mathrm{E}$ peroral memperbaiki kerusakan hepar akibat paparan rokok kretek sub kronik. Jurnal Kedokteran Brawijaya 24, 23-27

Nasution AS, Wirjadmadi B, Adriani M (2016). Efek preventif pemberian ekstrak kulit buah naga berdaging super merah (Hylocereus costaricensis) terhadap malondialdeid tikus wistar yang dipapar asap rokok. Jurnal Kedokteran Brawijaya 29, 21-24

Park EM, Park YM, Gwak YS (1998). Oxidative damaged tissue of rats exposed to cigarette smoke. Free Radicals Biology Medicine 25, 79-86

Prakash (2001). Antioxidant activity. Medallion Laboratories Analitical Progress 19, 1-4

Simanjuntak D, Sudaryati E (1998). Aspek pencegahan radikal bebas melalui antioksidan. Majalah Kedokteran Indonesia 48, 50-4

Soini P, Lehto VP (1998). Histopathological evaluation of apoptosis in cancer. The American Journal of Pathology 153, 1041-1053
Subandi (1999). Efek antioksidan (vit. C) terhadap jumlah fungsi makrofag alveoli serta kadar SOD jaringan paru tikus yang dipapar dengan asap rokok kronis. A dissertation. Malang, Universitas Brawijaya

Tirtosastro S, Murdiyati AS (2010). Kandungan kimia tembakau dan rokok. Buletin Tanaman Tembakau, Serat dan Minyak Industri 2, 33-43

Ulilalbab A, Priyanto AD, Maulana HI, et al (2012). Pemberian tablet effervescent rosella ungu menurunkan nilai MDA (malondialdehid) tikus wistar yang dipapar minyak jelantah. The Indonesian Journal of Public Health 9, 81-86

Usoh IF, Ekaidem IS, Etim OE, et al (2012). Antioxidant and hepatoprotective effects of dried flower extracts of Hibiscus sabdariffa $L$. on rats treated with carbon tetrachloride. Journal of Applied Pharmaceutical Science 02, 186-189

Valvanidis A, Haralambous E (2001). A comparative study by electron paramagnetic resonance of free radicals species in the mainsteam and sidestream smoke of cigarettes with conventional aceate filters and "bio-filters". Redox Report 6, 161-171

Voges E (2000). Tobacco encyclopedia. Tabac Journal International, Mainz, Germany 279p.

Vollmar B, Menger MD (2009). The hepatic microcirculation: mechanistic contributions and therapeutic targets in liver injury and repair. Physiological Reviews 89, 1269-1339

Yusmiati SNH, Arbai AMB, Tjokroprawiro A, et al (2012). Potensi antioksidan dalam ekstrak teh merah (Hibiscus sabdariffa) dan teh hijau (Camellia sinensis) terhadap proses aterogenesis pada tikus dengan diet aterogenik. JBP 14, 158-171 